\title{
The features of coping behaviour in patients with coronary heart disease
}

\author{
Cechy stylu radzenia sobie u pacjentów z chorobą wieńcową
}

\author{
Department of Psychotherapy, Federal State Educational Institution of Higher Education the Russian National Research Medical University named after N. I. Pirogov of the Ministry of Public Health \\ of the Russian Federation, Russian Federation, Moscow \\ Correspondence: Valeriia Alexeevna Manina, Department of Psychotherapy, Federal State Educational Institution of Higher Education the Russian National Research Medical University \\ named after N. I. Pirogov of the Ministry of Public Health of the Russian Federation, Str. Ostrovitiyanova, 1, 117997 Moscow, Russian Federation, tel.: 89225425440, e-mail: valeriamanina@gmail.com
}

\begin{abstract}
The article discusses the specific features of coping behaviour in patients with coronary heart disease. The authors indicate that an assessment of the features of coping behaviour in somatic patients, in particular those suffering from cardiovascular system diseases, is essential for improving the effectiveness of rehabilitation process. An analysis of the previous studies showed that patients with coronary heart disease are more likely to use such defence mechanisms as projection, intellectualisation, denial and coping strategies, such as repression and confrontation. The research objective was to identify the features of coping behaviour in patients with the painful form of coronary heart disease. The study involved 100 people: 50 patients with painful coronary heart disease and 50 with no history of cardiovascular disease, aged between 52 and 56 years. The main research methods included clinical interview; diagnostic methods: Life Style Index test; diagnostic method for coping strategies developed by E. Heim; Coping Inventory for Stressful Situations (CISS); Type of Person's Attitude towards the Disease test; methods of mathematical processing and statistical evaluation. Patients with the painful form of coronary heart disease use psychological defence mechanisms more often than healthy individuals. They also use non-adaptive types of coping as compared to healthy people of the same age. The obtained data also correlate with the type of person's attitude towards a disease: dominance of the sensitive type, the melancholic type of response, and the neurasthenic type. These features should be considered when developing a consistent approach to the rehabilitation programme with the psychocorrection of patients with coronary heart disease.
\end{abstract}

Keywords: coronary disease, illness behaviour, coping

Streszczenie W niniejszej pracy omówiono specyficzne cechy stylu radzenia sobie u pacjentów z chorobą wieńcową. Według autorów ocena cech stylu radzenia sobie u osób z chorobami somatycznymi, a w szczególności cierpiących na choroby układu krążenia, ma zasadnicze znaczenie dla poprawy skuteczności procesu rehabilitacji. Analiza wyników poprzednich badań wykazała, że pacjenci z chorobą wieńcową częściej uciekają się do takich mechanizmów obronnych, jak projekcja, intelektualizacja i zaprzeczenie, oraz strategii radzenia sobie typu wyparcie i konfrontacja. Celem niniejszego badania było zidentyfikowanie cech stylu radzenia sobie u pacjentów z dławicą piersiową stabilną. W badaniu wzięło udział 100 osób: 50 pacjentów z dławicą piersiową stabilną i 50 osób bez schorzeń układu krążenia w wywiadzie, w przedziale wiekowym od 52 do 56 lat. Główne metody badawcze obejmowały wywiad kliniczny; metody diagnostyczne: dotyczące oceny wskaźnika stylu życia (Life Style Index); metodę diagnostyczną strategii radzenia sobie opracowaną przez E. Heima; Kwestionariusz Radzenia Sobie w Sytuacjach Stresowych (Coping Inventory for Stressful Situations, CISS); test badający podejście pacjenta do choroby (Type of Person's Attitude towards the Disease); metody przetwarzania matematycznego i oceny statystycznej. Pacjenci z dławicą piersiową stabilną stosują psychologiczne mechanizmy obronne częściej niż osoby zdrowe. Wykorzystują ponadto nieadaptacyjne strategie radzenia sobie - również częściej niż osoby zdrowe będące w tym samym wieku. Uzyskane dane korelują z rodzajem podejścia do choroby: przewagą typu wrażliwego, melancholicznego i neurastenicznego. Cechy te należałoby uwzględnić podczas opracowywania spójnego podejścia do programu rehabilitacji obejmującego psychokorekcję pacjentów z chorobą wieńcową.

Słowa kluczowe: choroba wieńcowa, zachowanie w chorobie, radzenie sobie 


\section{INTRODUCTION}

$\mathrm{N}$ owadays medicine is inseparably associated with the introduction of modern methods of psychocorrection in the clinical treatment of somatic, psychosomatic and cardiac disorders, including painful attacks in coronary heart disease (CHD).

According to the World Health Organization (WHO), cardiovascular diseases (CVDs) took the lives of 17.9 million people in 2016 . They account for $31 \%$ of all deaths worldwide. A total of $85 \%$ of all CVD deaths are due to CHD, heart attacks and strokes.

This category of patients has certain features, both in terms of patients' response to stressful situations, and due to the specificity of the disease: pain syndrome manifests itself through the presence of a stress factor as well as the inability to express one's feelings verbally.

The interrelation between behavioural aspects and the level of emotion regulation as well as indicators of somatic health was also studied by Kubzansky et al. (2011), and it corresponded with the previous study on the interrelation between emotion regulation and the risk of developing cardiovascular diseases.

A high level of self-regulation is associated with a $20 \%$ reduction in the risk of CHD. The ability to manage thoughts, feelings, and behaviour was studied by researchers for 13 years and showed that high levels of specific forms of selfregulation reduce the potential risk of CHD (Kubzansky et al., 2011).

Strategies of non-adaptive regulation in the case of untimely awareness of emotions increase the risk of adverse somatic outcomes, while adaptive strategies contribute to the improvement of somatic and physical health (Rozanski et al., 2005).

The period of formation of emotions in childhood predetermines a set of strategies that a person acquires in the process of maturation and socialisation, gaining experience and forming a set of strategies from one's own experience (John and Gross, 2004).

Chiavarino et al. (2015) assessed patients with acute coronary syndrome for the level of anxiety, depression and stress coping strategy in the acute period and after 3 months. The authors found that patients focused on emotional overcoming of the disease recovered better and faster compared to those using dysfunctional strategies, which correlated with the indicators of the left ventricular ejection fraction (Chiavarino et al., 2015).

Zou et al. (2017) assessed the health supporting behaviour and the mediated effect of the coping behaviour to overcome stress in patients with CHD. They found that having self-esteem and a preference for choosing confrontation as a way of coping with stress indeed helps form health supporting behaviour, while confrontation is partially mediated in the interrelation between a selfassessment of strengthening of healthy behaviour (Zou et al., 2017).
Gureeva (2017) found that denial is the leading mechanism in patients with CHD. Her study considered the denial of CHD by patients as a substitution of the concept when, while receiving attention from others, only positive information is perceived, while negative information is blocked at the very beginning of the presentation of information from others. Intellectualisation is a typical defence mechanism where a patient uses a certain schematisation to accompany the interpretation of an event in order to develop a sense of subjective control over oneself and others (Gureeva, 2017).

According to Trufanova (2008) projection is the leading mechanism of psychological protection in CHD patients, who attribute their shortcomings and defects not to themselves, but to those around them.

Correlation analysis allowed Zubareva (2014) to reveal that CHD patients with the "confrontation" coping strategy react aggressively and bitterly to disease exacerbation. Patients who were concerned about the fact that someone might find out about their disease, and so they would make a negative impression on others, preferred "repression" coping strategy (Zubareva, 2014).

Thus, the analysis of psychological and medical literature showed that patients with CHD have certain features of response to a disease as well as features of protective mechanisms and coping-behaviour strategies usage. In particular, in a situation of $\mathrm{CHD}$, the ability of patients to control their emotional reactions is extremely important, while some authors emphasise the use of such mechanisms of protection as projection, intellectualisation, denial and coping-strategies of repression and confrontation as the most characteristic for patients with CHD.

At the same time, it is noted that the recovery of patients whose coping strategies were aimed at overcoming a difficult situation was more effective than of those who used strategies of avoiding or denial.

\section{MATERIAL AND METHODS}

A total of 50 patients with painful CHD, including 26 men and 24 women aged 52 to 56 years, participated in the study. The control group included 50 people with no history of cardiovascular diseases. The control group included 25 men and 25 women aged between 52 and 56 years.

The condition of the subjects in the study group met the criteria of the International Statistical Classification of Diseases and Related Health Problems (ICD-10) section: CHD (I20, I21, I24, I25), namely: painful form of CHD. This group included patients with the following clinical diagnoses, which were the clinical criteria for inclusion in the study:

- angina of effort functional class II, III, IV (17 people);

- acute myocardial infarction (8 people);

- atherosclerotic heart disease (12 people);

- coronary thrombosis (3 people);

- CHD with rhythm and conduction disorders (10 people). 
The general exclusion criteria were:

- any stage of pregnancy;

- a combination of hypertension and CHD;

- repeated myocardial infarction;

- surgical treatment;

- signs of a formal attitude to filling in the questionnaires. The study was conducted in the Central Clinical Hospital of the Russian Academy of Sciences.

Research methods:

1. clinical treatment and clinical interview;

2. diagnostic methods: Life Style Index test; diagnostic method of coping strategies developed by E. Heim; Coping Inventory for Stressful Situations (CISS); Type of Person's Attitude towards the Disease test;

3. Methods of mathematical processing and statistical evaluation of data using Microsoft Excel 2007 and SPSS 10.0 for Windows (the Mann-Whitney $U$ test was used for the intergroup analysis of differences).

The study was approved by the local ethical committee of the Russian National Research Medical University named after N.I. Pirogov.

\section{RESULTS AND DISCUSSION}

The analysis of the results of the study according to the Life Style Index test showed that psychological defence systems - "denial" ( $U=80)$, "compensation" ( $U=61)$, "intellectualisation" $(U=60.5)$ are distinct in the structure of the psychological defence mechanisms of CHD patients with pain syndrome compared to healthy people.

The analysis of the results revealed the peculiarities of patients: they use a more "mental way of overcoming experiences" through rationalisation and intellectualisation as forms of defence mechanism.

The results of the Heim's coping mechanisms test allowed us to analyse the severity of coping mechanisms separately for three types: cognitive, emotional, behavioural.

In terms of cognitive coping strategies, ignorance $(P=0.026, p \leq 0.05)$, relativity $(P=0.006, p \leq 0.05)$, and confusion $(P=0.003, p \leq 0.05)$ prevailed in patients with $\mathrm{CHD}$ compared to the control group.

As for the emotional coping strategies, coping - suppression of emotions ( $P=0.027, p \leq 0.05)$, and emotional discharge $(P=0.02, p \leq 0.05)$ prevailed among patients with CHD. The group of healthy people used optimism $(P=0.005$, $p \leq 0.05)$.

This suggests that the behaviour characterised by a desire to temporarily avoid solving problems is common for these patients, while relatively healthy people use altruism coping strategy.

The analysis of CISS results showed that patients with the painful form of CHD use problem-oriented coping $(P=0.006, p \leq 0.05)$, avoidance-oriented coping $(P=0.012$, $p \leq 0.05)$, and social distraction $(P=0.027, p \leq 0.05)$ compared to the control group.
Furthermore, it can be concluded based on the obtained results that both groups resorted to emotionally-oriented coping and distraction without statistically significant differences.

We have additionally analysed the severity of coping strategies in two groups depending on gender characteristics. When analysing gender differences, we found that there were statistically significant differences depending on gender. Women were more focused on problem-oriented coping $(P=0.046, p \leq 0.05)$, avoidance coping $(P=0.075, p \leq 0.05)$ and social distraction $(P=0.048, p \leq 0.05)$ in the group of $\mathrm{CHD}$ patients with pain syndrome. In the group of healthy individuals, coping strategies for females were as follows: emotionally-oriented coping $(P=0.026, p \leq 0.05)$ and avoidance coping $(P=0.041, p \leq 0.05)$.

The analysis of the severity of depression according to the Beck scale revealed that the study group is more often characterised by the severity of depressive tendencies $(\mathrm{U}=161.5)$, and that the respondents from the female group had more distinct depressive features (moderate degree).

Analysing the results of the Type of Person's Attitude towards the Disease test, the following was identified: the predominance of the sensitive type, the melancholic type of response, and the neurasthenic type. These types are maladaptive. We identified correlations between the results of the Type of Person's Attitude towards the Disease test and the Beck scale. Thus, high rates of depressive tendencies corresponded to those of a sensitive type of correlation $(P=0.005, p \leq 0.05)$, and the anosognosia type $(P=0.049$, $p \leq 0.05)$. This category of patients belongs to the group of psychosomatic disorders due to the particular response of patients in a stressful situation, and because of the specificity of the disease: pain syndrome manifests itself with the presence of a stress factor, and when there is a state of inability to verbally express the feelings.

The therapy of CHD involves an integral rehabilitation system, which includes medical correction, proper nutrition, water-salt balance, physical exercises in the framework of physical therapy and psychocorrectional work.

Katathym imaginative psychotherapy allowed for reducing self-stigmatisation in the study groups.

Thereby, we believe that psychotherapeutic correction takes the leading role in the treatment of patients with CHD.

The formation of healthy behaviour was also ensured by means of cognitive-behavioural therapy, by keeping a diary and an objective assessment by the patient of their condition. Drawing was performed immediately after the visually formed image of the "motive." The discussion of the patient's state during visualisation and what was happening in the "image" version allowed to work out the patient's current state of treatment, taking into account the emotional state, feeling in the chest, and general physical well-being. Medication was adjusted by a cardiologist, who objectively assessed the condition of hospitalised patients on a daily basis. 


\section{CONCLUSIONS}

The analysis of the theoretical references to the problem of CHD allowed us to identify the main features and personality traits of coping strategies used by patients with painful CHD. In particular, we found that patients with CHD are most likely to use such defence mechanisms as projection, intellectualisation, denial and coping strategies of repression and confrontation.

We assessed 100 individuals, including the study group of patients with painful CHD and the control group - healthy people age-matched to the study group and with no history of cardiovascular diseases.

The study allowed us to identify a number of features:

1. Psychological defences of "denial," "compensation," and "intellectualisation" are distinct in the structure of the mechanisms of psychological protection in CHD patients with pain syndrome compared to healthy individuals.

2. As for the cognitive coping strategies, patients with $\mathrm{CHD}$ are more likely to use ignorance, relativity and confusion compared to the control group. As for the emotional coping strategies, CHD patients are dominated by coping - suppression of emotions and emotional discharge. In the group of healthy people, it is optimism. As for the behavioural coping strategies, patients with $\mathrm{CHD}$ pain syndrome preferred coping strategies such as compensation, active avoidance and cooperation. The following non-adaptive forms of coping strategies were identified for patients with CHD pain syndrome: problem-oriented coping, coping aimed at avoidance, social distraction.

3. Women in the group of patients with CHD pain syndrome were more focused on problem-oriented coping, avoidance coping and social distraction. In the group of healthy individuals, coping strategies such as emotionally-oriented and avoidance-oriented coping, were used by women.

4. The following features of the attitude towards the disease were revealed in the study group: predominant sensitive type, melancholic type of response, and the neurasthenic one.

Thus, we identified psychological characteristics of patients with CHD, namely the use of a number of psychological defence mechanisms, coping strategies and types of response to the disease. These features allowed us to differentiate this group of somatic patients, which will increase the effectiveness of therapy and rehabilitation. It may be concluded that patients with painful CHD use non-adaptive types of coping compared to age-matched healthy individuals.
These features should be considered when developing a consistent approach to the rehabilitation programme with the psychocorrection of patients with CHD.

As a further direction of the research, it can be noted, firstly, the selection of nosospecific factors that increase the effectiveness of therapy and rehabilitation. Secondly, the construction of a structural model for the provision of medical and psychological assistance to patients with cardiovascular diseases, including diagnosis, therapy, rehabilitation and prevention in a single process, taking into account the identified features.

An integrated treatment approach for CVD patients also includes an assessment of their psycho-emotional condition, personality traits and attitude towards the disease, which will help create an optimal rehabilitation program.

\section{Conflict of interest}

The authors do not report any financial or personal affiliations to persons or organisations that could negatively affect the content of or claim to have rights to this publication.

\section{References}

Chiavarino C, Bianchino C, Brach-Prever S et al.: Theory of mind deficit in adult patients with congenital heart disease. J Health Psychol 2015; 20: 1253-1262.

Gureeva IL: [Psychological characteristics of patients suffering with panical attacks based on ischaemic heart disease]. Problems of modern teacher education, Yalta 2017.

John OP, Gross JJ: Healthy and unhealthy emotion regulation: personality processes, individual differences, and life span development. J Pers 2004; 72: 1301-1333.

Kubzansky LD, Park N, Peterson C et al.: Healthy psychological functioning and incident coronary heart disease: the importance of self-regulation. Arch Gen Psychiatry 2011; 68: 400-408.

Rozanski A, Blumenthal JA, Davidson KW et al.: The epidemiology, pathophysiology, and management of psychosocial risk factors in cardiac practice: the emerging field of behavioral cardiology. J Am Coll Cardiol 2005; 45: 637-651.

Trufanova OK: [Features of the psychological time of personality with chronic somatic diseases]. North Caucasian Psychological Herald, Rostov-on-Don 2008.

Zou H, Tian Q, Chen Y et al.: Coping styles mediate the relationship between self-esteem, health locus of control, and health-promoting behavior in Chinese patients with coronary heart disease. J Cardiovasc Nurs 2017; 32: 331-338.

Zubareva OA: [The correlation of coping behaviour with the types of attitudes towards the disease in patients with acute forms of coronary heart disease]. Uchenye zapiski St. Petersburg State Medical University. I.P. Pavlova, St. Petersburg 2014. 